http://dx.doi.org/10.30681/23588403v14i0110

\title{
CONSTRUCTION OF CULTURAL IDENTITY OF VAQUEIRO IN 'O SERTANEJO' [THE BACKLANDS] OF JOSÉ DE ALENCAR
}

\author{
Lucas Andrade de MORAIS (UERN) ${ }^{1}$ \\ Data de recebimento: $18 / 07 / 2020$ \\ Data de aceite: $26 / 09 / 2020$
}

\begin{abstract}
Resumo: A representação do homem sertanejo na literatura é apresentada por meio das tradições, valores e crenças construídas naquele espaço, nesse processo tem-se o vaqueiro como um genuíno sertanejo, por possibilitar a interiorização do nordeste, surgindo o sertão. Por isso, esse trabalho tem como proposito identificar como é construída a identidade cultural do vaqueiro no projeto regionalista alencariano. Na discussão utilizara como aportes teóricos sobre o contexto sócio-histórico do vaqueiro e da vaquejada em Cascudo (2008) e Magalhães (1970), identidade cultura em Hall (2006), cultura e cultura popular em Ayala \& Ayala (1987), Santos (1992), Bosi (1992) e Bauman (2001) e literatura sertanista em Sodré (1964) e Bosi (1994). O corpus da pesquisa é a obra 'O sertanejo' (1875) de José de Alencar. Os resultados demostraram que a construção da identidade cultural do vaqueiro na literatura alencariana existência de elementos físicos, sócioafetivos e simbológicos que são marcas da identidade do vaqueiro e que podem sofrer ressignificação, adaptando-se diante das novas relações sociais e contextos culturais.
\end{abstract}

Palavras-chave: Identidade. Cultura. Vaqueiro. Sertanejo. José de Alencar.

\begin{abstract}
The representation of sertanejo man in literature is presented through traditions, values and beliefs constructed in that space, in this process we have vaqueiro as a genuine "sertanejo", because it allows interiorization of northeast, appearing the sertão. Therefore, this article aims to identify how cultural identity of vaqueiro is constructed in regionalist project of Alencariano. In the discussion it used as theoretical contributions about socio-historical context of vaqueiro and the vaquejada in Cascudo (2008) and Magalhães (1970), identity culture in Hall (2006), culture and popular culture in Ayala \& Ayala (1987), Santos (1992), Bosi (1992) and Bauman (2001) and sertanist literature in Sodré (1964) and Bosi (1994). The corpus of research is literary work 'O sertanejo' [The Backlands] (1875) by José de Alencar. The results showed construction of cultural identity of vaqueiro in Alencarian literature has physical, socioaffective and symbolic elements are marks of identity of vaqueiro and can be resignified, adapting to new social relations and cultural contexts.
\end{abstract}

Keywords: Identity. Culture. Vaqueiro. Sertanejo. Jose de Alencar.

\section{Introduction}

\footnotetext{
${ }^{1}$ Doutorando em Letras pela Universidade do Estado do Rio Grande do Norte (UERN). Pau dos Ferros, Rio Grande do Norte, Brasil. lucasmorais7@gmail.com.
} 
The search for a national cultural identity, that is, for a Brazilian identity, is marked in literary field by the projection of myth and hero, born in the 19th century. In this scenario one finds formation of northeastern cultural identity in literature, initiated in romanticism period, through so-called regionalist literature (or sertanista) with an approach focused on the spatial, political and social characteristics of sertão (backlands).

The representation of sertanejo man in literature is made through traditions, values and beliefs constructed in that space, appearing characters that become heroes in collective memory of sertanejo people. In the construction of cultural identity of sertanejo man, we have the image of vaqueiro as a genuine sertanejo, for being one of figures that made possible the process of interiorization of northeast, with the clearing of virgin forests and fixation in interior, thus appearing the sertão (backlands).

It is in this environment that one of first vaqueiros in national literature appears, presented by the Ceará author José de Alencar in his last work published in life: "O sertanejo" [The Backlands] (1875). The book brings narrative of novel "sertanejo" situated in Quixeramobim (CE), having as main character Arnaldo, a vaqueiro from Ceará, who for personal ideals and love, fights in his trade to win respect and recognition of his boss and his sister sympathy.

Knowing socio-historical relevance of vaqueiro in formation of Brazilian (and northeastern) people and socio-cultural representation of vaqueiro and vaquejada in sertaneja culture. Bearing in mind that practice of "vaquejada" is associated with vaqueiro work of separating cattle, as a practice in management of "tinhoso" animal that entered caatinga vegetation, and that its first configuration is associated with training of vaqueiro on farms, soon after, this practice began to gather a number of people, until it became a "very popular party in sertão" (CASCUDO, 2008, p. 901), and then began to influence construction of identity of vaqueiro. Therefore, it is relevant to understand: How did construction of cultural identity of vaqueiro occur in regionalism literature (sertanista)?

For this reason, the authors who portrayed vaqueiro in their literary works were rescued from Brazilian literature, electing the book: 'O sertanejo' [The Backlands] (1875), by José de Alencar, one of first literary works to portray and insert vaqueiro as a national identity.

Starting from this narrative, general objective of present investigation is to identify how cultural identity of vaqueiro is constructed in José de Alencar's 'O sertanejo'. And as specific objectives: to present concepts and contexts that constitute in identity of vaqueiro and the vaquejada; to discuss about concepts of culture in perspective of sociological and cultural 
studies; And, at the end, to present construction of cultural identity of vaqueiro in alencariano regionalist project of sertanejo.

\section{Culture(s): the various concepts}

The definition of "culture" is not peaceful and has multiple meanings. Therefore culture is understood as a concept in which "complexity" (MORIN, 2007) is present. The various individual and collective events and social, political and economic transformations are intrinsically related to each other, complementarily and antagonistically, and thus produce the historical transformations in course of time affect understanding of culture.

In a broad, or anthropological, sense, everything human being does and produces, to live with each other, is considered culture (SANTOS, 1992). In Bosi's vision (1992) culture is conceptualized from linguistic and etymological aspects of term, coming from latin term "colo", which means to occupy earth, so culture would come from future of this verb, meaning what will be worked, what one wants to cultivate, not only in agricultural sense, but in transmission of values and knowledge from one generation to another, thus "[...] is set of practices, techniques, symbols and values must be transmitted to new generations to ensure reproduction of a state of social coexistence" (BOSI, 1992, p. 16).

For Geertz (2008, p. 38) "[...] culture has modeled us as a unique species - and no doubt it is still modeling us - so it also models us as separate individuals". Culture is something should be perceived and not something should be defined. Its conception of culture is associated with concept of abstraction, since culture would not be something fully localizable, but a great mechanism for the production of shared meanings in social bosom, assuming a material or immaterial form, present anywhere, being linked to field of language in which subjects name, signify and give meaning to social objects/practices. Therefore, it is everything that is shared and transmitted in public space.

Sociologists Brym, Lie \& et ali (2006) understand culture as sum of ideas (abstraction), practices (cooperation) and material objects (production) shared by individuals for purpose of adapting to their environments. In field of culture, authors identify three typologies: "High Culture" (or Erudite Culture), Mass Culture and Popular Culture.

Erudite Culture is characterized as that consumed (and generally produced) by the economically higher classes. Mass Culture is that consumed by all social classes, whose elements are transmitted and spread by mass media. Popular Culture, also consumed by all 
classes, is based on conceptions, values and objects can be considered traditional of a community or social groups (BRYM, LIE \& et ali, 2006).

In this article, understanding of popular culture is of interest, since vaquejada is inserted in this "typology" of culture, being therefore a synonym of "culture of the people" marked by practice and conditions of production of groups and communities considered subordinate in structuring of social classes (AYALA \& AYALA, 1987; ARANTES, 1990).

It is Popular Culture, of great incidence in Northeastern Region, is intertwined in majority of historical formation of Brazilian people, and especially in formation of cultural identity of Northeastern people. It is in tradition, which constitutes folkloric praxis, forms popular culture. In this panorama it is possible to find several cultural manifestations, such as: dance, music, arts/crafts, string literature and popular poetry, and it is also possible to insert practice of vaquejada, as a party and/or popular northeastern cultural practice.

The vaquejada, as a popular cultural manifestation, was not exempt from influences of "liquid modernity" (BAUMAN, 2001). Understanding that modernity is not a threat to popular culture, since it is alive and dynamic, being reconstructed, resignified and transformed according to time, space and communities and social groups that produce it. This is also identity of subjects who practice this culture, because identity is a process of construction:

[...] guided by logic of rationality of objective (discovering how attractive objectives are that can be achieved with means one has). Task of the identity builder is, as Lévi-Strauss would say, of a bricoleur, who builds all sorts of things with material he has at hand (...). (BAUMAN, 2005, p. 55).

Identity constitution and concept of culture, receives influence of modern liquidity, becoming unstable. Identities and cultures become hybrids and displaced from a local bond, as Canclini (2013, p. 19) understands "[...] by hybridization [the] sociocultural processes in which discrete structures or practices, which existed separately, combine to generate new structures, objects and practices".

In this complex scenario, cultural tradition of vaquejada practices and the identity formation of vaqueiro is not erased by industrialization of symbolic property (CANCLINI, 2013) or "Cultural Industry" (ADORNO, 2002), but restructured, in order to adapt the new practices, needs and social environments and thus give continuity to their identity. 


\section{Vaqueiro and vaquejada: concepts and identity contexts}

The vaquejada, as a socio-cultural expression and practice, originated in Northeastern Brazil between 17th and 18th centuries. Action of vaqueiro "colonizer" rural life of region, with work of taking and gathering cattle herd (raised loose in caatinga vegetation), was one actors made possible process of interiorization of northeastern territory:

It was they who first penetrated and broke through steep sertão in a sharp struggle against virgin nature, the treacherous Indians and the wild beasts, setting up corrals, populating land, laying stable foundations of our economic structure and setting up a rural society. (MAGALHÃES, 1970, p. 101).

Cattle were responsible for main activity in region. That is why importance of vaqueiro's work driving the cattle "[...] through these great distances in herds of hundreds of animals. Crossing inhospitable regions, where even water is scarce and often non-existent (...), cattle arrive naturally maimed at their destination" (PRADO JR, 1972, p. 68), and amidst absolute absence of roads, lack of water and confrontation of xerophytic caatinga vegetation emerges the sertão as a place, and to vaqueiro is due a part in formation of this space, and for at least three centuries of evolution, of cultural identity of the sertanejo people.

The vaqueiro, however, was created in opposite conditions, in a rare, disturbed intermittence, of happy hours and cruel hours, of plenty and misery - having over his head, as a perennial threat, the sun, dragging of wrapping in the volver of seasons, successive periods of devastation and misfortune. (CUNHA, 1984, p. 52).

Identity of vaqueiro as "settlers of sertão" derives from memory and socio-historical construction this figure assumed in the popular imagination, as a result of narratives (incorporated into folklore of sertanejo people) of heroes in leather armor, about work, way of living and the struggle/losses in clearing process of region they set out to "conquer". All this construction and exchange of experiences of generations projected an image of what it is to be a vaqueiro, and as a product of cultural environment:

Identity is formed in "interaction" between self and society. The subject still has a core or essence that is the "real self", but this is formed and modified in a continuous dialogue with the "outside" cultural worlds and identities these 
worlds offer. Identity, in this sociological conception, fills space between "inside" and the "outside" - between personal world and public world. The fact we project "ourselves" into these cultural identities while internalizing their meanings and values, making them "part of us" contributes to aligning our subjective feelings with objective places we occupy in social and cultural world. The identity, then, stitches (or, to use a medical metaphor, "sutures") the subject to the structure. It stabilizes both subjects and cultural worlds they inhabit, making both more unified and predictable. (HALL, 2006, p. 11-12).

Therefore, historical construction of identity of vaqueiro, as a hero, is part of his interaction in environment, and which is based on "collective memory" (HALBWACHS, 2003) of sertanejo people, in conceiving him as one who tangled the oxen, opened roads and entered the caatinga (vegetation) with his leather clothes, and who, for many times, had to deal with wild animals of his flock and knock down by tail in the middle of sertão, as Cascudo (2008, p. 901) portrayed:

[...] the vaquejada, itself, [was] the game of knocking the animal down, pulling it abruptly by tail, vaqueiro going horseback. There are always two riders running and the one on left is the mat, to keep the animal in a certain direction. Paired rider with bull, ox or cow, bringing horse closer, vaqueiro holds tail of animal giving a strong pull and, in same minute, pushing horse away.

It is possible to notice historically the vaquejada appeared as usual management practice of rebel cattle ran away from herd and entered caatinga, and it was then up to vaqueiro to go into the woods and capture this animal by dropping it by the tail, and then bring it back to the herd. On farms this practice of capturing the ox by tail was repeated as a form of training, later giving rise to the vaquejada as a feast of popular culture in sertão, organized and would originate, a priori, in poor layers of society.

Thus, the vaquejada arises from practice of work, which around 1940, the vaqueiro began to meet and demonstrate their skills in events (tournaments) organized by farmers (CASCUDO, 2008), and then assumed a new feature, the practice of sports, treated as a big economic business.

Memory of the vaquejada as a historical practice of work and of cultural identity of vaqueiro, are located in a time and space differentiates itself from the events and experiences of the current context and interests that revolve around the vaqueiro and vaquejada theme, this because "Identity becomes a mobile celebration: continuously formed and transformed in relation to forms by which we are represented or challenged in cultural systems around us" 
(HALL, 2006, p.13 ), as well as memory, which is something dynamic goes through a process of reconstruction and resignification, adapting itself in face of new social relations and cultural contexts.

\section{4 'O Sertanejo' [The Backlands] and the construction of cultural identity of vaqueiro}

Representation of sertanejo identity in Brazilian literature began in second half of 19th century, in period of romanticism, precisely in regionalist or sertanist phase, where novels of that period sought to deal with social themes concerning spaces of the Brazilian interior territories.

[...] the fundamental concern of sertanism, which thus replaces Indianism, as a formal and insistent aspect of intention to transfuse a national sense into romantic fiction. Such concern is important in condemning the coastal and urban picture with that in which the external influence appears, as a false Brazil. True Brazil, original Brazil, pure Brazil would be that of interior, that of the sertão [backlands], immune to external influences, preserving in a natural state national traits. (SODRÉ, 1964, p. 323).

In this panorama, José Martiniano de Alencar, born in Messejana (Ceará), was first author to insert figure of "sertanejo" (and vaqueiro) as one of eminently Brazilian identities. The author entered with his literature in the sertões (backlands) of Ceará, seeking to create characters represent genuine roots of Brazil, addressing small particularities of region, use and customs and language that characterized the sertão.

The various forms of sertanism (romantic, naturalist, academic and even modernist) have plastered our lyrics since middle of last century, were born from contact of a citadine and literate culture with raw material of rural, provincial and archaic Brazil. As the writer cannot do pure folklore, he limits himself to projecting his own interests or frustrations in his literary journey around countryside. The graft often results in a hybrid prose where mirror of wild life and ideological and aesthetic models of prose do not reach point of artistic fusion. (BOSI, 1994, p. 154).

"O Sertanejo", published in 1875, is one of novels Alencar's sertanista. The book is divided into two parts, the first narrates landscape of the sertão and the second deals with plot. Literary work is set in year 1765 (18th century) and portrays the history of Arnaldo Loureiro, a 
vaqueiro from state of Ceará from Quixeramobim, who works for Captain Major Gonçalo Pires Campelo, and ends up nurturing a love for his boss's sister, Dona Flor.

The narrative space of literary work is the sertão, projected over three spaces: geographic, social and mythical, being last "[...] a category constructed, throughout history, through various narratives, in order to constitute a given image about places and people" (SILVA, 2010, p. 30). The aesthetic and social elements of the sertão are configured as very cultural environment influences construction of identity of vaqueiro, since idea and image of the sertão and physical, social and cultural characteristics are inseparable from way of life of vaqueiro.

The sertão of Alencar is part of commonplace romantic ideology, so configuration of sertaneja image is seen from perspective of beautiful landscapes, from nostalgia of beautiful and majestic place from which it came, leaving in background socio-economic problems such as backwardness, colonelism, drought and misery (SILVA, 2010).

It is in this context structured in 'O Sertanejo', that José de Alencar shows the first records of constructions of the cultural identity of vaqueiro in Brazilian literature. The character Arnaldo Loureiro, "[...] a young man of twenty years, of regular stature, agile, and slender of the talhe. His face was shaded, sunburned, and his face was as black as long hair hung around his neck. His eyes, torn and vivid, gave veins of an indomitable heart" (ALENCAR, 2013, p. $13)$, is first representation of vaqueiro hero in literature:

To shape the hero, Alencar saw no more effective way than to amalgamate him with the life of nature. It is connaturality that enchants him: from the lines of the profile to the gestures that define a character, everything emerges from the same unconscious and wild background, which is the very matrix of romantic values. (BOSI, 1994, p. 104).

Very name "Arnaldo" has its meaning tied to the ideas of "eagle power" or "what is strong like eagle", recalling all characteristic of dexterity, readiness, vision and perception of character, these very characteristics are attributed to vaqueiro, that in their work it is necessary readiness, strength and dexterity to dominate animals and the sertões, confirming Bosi's idea (1994) about the formation of the hero of Alencar's literature, and can see in this passage:

There he camels the fearless vaqueiro from Ceará, who chases indomitable bull in thickest cerrado to horse's hoof, and derrifies him by the tail with admirable dexterity. There, at death of day, rejoices between mooing of reses, nostalgic and plangent voice of boy who aboys the cattle to collect to corrals in time to brand it. (ALENCAR, 2013, p. 13). 
This first characteristic identity of vaqueiro of sertões northeast, a strong, agile, fast and courageous man. It is because of this configuration vaqueiros, knights of sertões, as well as medieval knights, are faithful subjects of their bosses and his family, giving up their own lives to be always alert to services of their masters:

The mirror was symbolic vision of natural forces. The hearing of tree, smell of animal, ardor of blood and instinct: these are primordial myths will be worth, in Alencar's code, purity, loyalty, courage. Both in nativist novels ( $O$ Guarani, Iracema, Ubirajara) and in those in which the good savage unfolds into regional heroes ( $O$ Gaúcho, $O$ Sertanejo), seal of nobility is given by forces of blood that the author recognizes and respects equally in lineage of white colonizers. (BOSI, 1994, p. 103).

The vaqueiro Arnaldo shows himself to be a faithful subject to his master (Captain Major), when he tries to protect him and also his relatives, "[...] but I do not allow anyone in this world to offend Captain Major and his family; therefore, if you do not abandon your project be sure you will find me ahead" (ALENCAR, 2013, p. 41). Fidelity between vaqueiros and their bosses has its origin in heredity of profession, because functions are passed from father to children, and those raised from an early age in family environments of bosses, end up developing an affective family bond.

[...] Arnaldo knows how much we cherish son of the one who was our vaqueiro and friend, the good Louredo, may God have in his holy peace. [...] We hope there will be no more faults like this, that they will put us in the hard need to forget affection that we deserve. You know, Arnaldo, that we have destined to you place that served your father, our first vaqueiro. (ALENCAR, 2013, p. 98).

The vaqueiro's craft itself is something has been learned since childhood, where poorest children, who are born and live in the sertão, have the vaquejada as main craft of sertanejos, much more than a job, it becomes a means of life, an identity of sertanejo man.

Arnaldo waited for ox on foot; his companions, seeing animal fall on him, judged him crushed. But intrepid vaqueirinho work held horns of beast and jumped on his neck. [...] But little boy, standing on his rump, reached bunch of catolés [tree] and cut it off. After that, jumping on ground, he came to present the Flower with his conquest, as glorious as that of the golden pomos de hespéride. (ALENCAR, 2013, p. 245). 
Another outstanding characteristic in identity of vaqueiro are clothes, made of leather, with special characteristics to deal with vegetation of sertão, since vaqueiro of sertão besides connecting with wild cattle, needed to deal with dry climate and vegetations of caatinga, made up of plants with few leaves and thorns:

In general these people had adopted a costume in which Portuguese fashion of the time was modified by influence of sertão. However, they wore a green gibbon garnished with white gallon, a yellow dress and shorts of same color with black boots and frederica hats. They had a wide catana, a shoulder strap and a dagger, in addition to pistols in their holsters, which completed equipment of these individuals whose sinister features already inculcate more fright than weapons themselves. They brought more, attached to saddle and suspended from animal's hips, the wide axe served them in case they needed to open the bite in virgin forest, or improvise a bridge over the full river: an indispensable tool at time for the traveller, who often turned it into a terrible weapon [. ...] Even today this picturesque and traditional sertanejo costume, and more especially that of vaqueiro, retains little difference from old Portuguese fashion, for which first leather clothes were cut. (ALENCAR, 2013, p. 12;19).

Therefore, it is understood construction of image of vaqueiro of sertão has in his garments an armor to deal with fights fought in northeastern sertão, where the clothing is one of the main cultural identity aspects of vaqueiro of sertão, because this trait lasted for a while until it became a characteristic mark of vaqueiro, together with values, senses and symbols of sertanejo, marked by peculiarity of behaviour, language and work, has in its personal characteristics and in the aesthetic signs of the identity of vaqueiro when differentiating or identifying him from another group.

\section{Conclusion}

Construction of cultural identity of vaqueiro is intrinsic to construction of image of sertão, since very emergence of the sertão is due, in part, to vaqueiro. That is why image of a hero of sertão is represented in his constant struggle for survival in a semi-arid region, with scarce resources, social backwardness and drought problems.

Representation of vaqueiro and the practice of the vaquejada as a cultural manifestation in countryside is presented in various contexts, practices, memories and arts, one 
of these is literature, which although it is based on fiction, is an instrument for understanding social and cultural reality of a given moment.

This is the case of the works of regionalist or sertanist literature sought to (re)construct an image of interior of the country, whose sertão has been space for the setting of some narratives of this period begun in Brazilian romanticism and continued in other literary periods, where various interpretations and narratives about notions of sertão emerge.

The "sertão alencariano" in literary work "O Sertanejo" is not marked by centralization of social, environmental and political problems, but in a space of construction of prosperity, beauty and majestic charms. This does not fail to represent harsh reality of sertanejo people, since narrative itself subtly addresses relationships in which problems of explorations of sertanejos are highlighted.

In the literary work analyzed, José de Alencar construe romantic image of vaqueiro Arnaldo as a hero. A medieval knight, who is faithful to his boss/kings and fights for recognition/love of his beloved. In the field of building the cultural identity of vaqueiro, it was possible to perceive existence of elements: physical (dexterity, agility, strength and courage), in dealing with flocks and wilderness; socio-affective (heredity, subservience, fidelity, passion), in relation to bosses and their history; and, symbolic (clothing, weapons, instruments of work), that identify them and differentiate them from other groups.

Therefore, construction of cultural identity of vaqueiro in Alencarian literature represents a part of mythological imaginary of being a vaqueiro and the making of vaqueiro (vaquejada), so some of elements of identity of vaqueiro may suffer resignification, adapting to the new social relations and cultural contexts.

\section{References}

ADORNO, T. W. Indústria cultural e sociedade. São Paulo: Paz e Terra, 2002.

ALENCAR, J. O sertanejo. 3. ed. São Paulo: Martin Claret, 2013.

ARANTES, A. A. O que é cultura popular. 14. Ed. São Paulo: Brasiliense, 1990.

AYALA, M.; AYALA, M. I. Cultura popular no Brasil. São Paulo: Ática, 1987.

BAUMAN, Z. Identidade: Entrevista a Benedetto Vecchi. Tradução de Carlos Alberto Medeiros. Rio de Janeiro: Zahar, 2005.

Modernidade Líquida. Rio de Janeiro: Zahar, 2001.

BOSI, A. Dialética da colonização. São Paulo: Companhia das Letras, 1992. 
BOSI, A. História concisa da literatura brasileira. São Paulo: Cultrix, 1994.

BRYM, R.; LIE, J.; HAMLIN, C. L.; MUTZENBERG, R.; SOARES, E. V.; SOUTO MAIOR, H. Sociologia: sua bússola para um novo mundo. São Paulo, Thomson, 2006.

CANCLINI, N. G. Culturas híbridas: estratégias para entrar e sair da modernidade. São Paulo: Editora da Universidade de São Paulo, 2013.

CASCUDO, L. C. Dicionário do folclore brasileiro. 10. ed. Rio de Janeiro: Ediouro, 2008.

CUNHA, E. Os Sertões. São Paulo: Três, 1984.

GEERTZ, C. A interpretação das culturas. Rio de Janeiro: Guanabara Koogan, 2008.

HALBWACHS, M. A memória coletiva. Tradução de Beatriz Sidou. São Paulo: Centauro, 2003.

HALL, S. A identidade cultural na pós-modernidade. 11. ed. Rio de Janeiro: DP\&A Editora, 2006.

MAGALHÃES, J. O vaqueiro na história do ceará. In: STUDART FILHO, C. (Org.). Revista do Instituto do Ceará. Tomo LXXXXIV. Ano LXXXIV. Fortaleza-CE, 1970.

MORIN, E. Introdução ao pensamento complexo. 3. ed. Porto Alegre: Sulina, 2007.

PRADO JR., C. História Econômica do Brasil. 15. ed. São Paulo: Brasiliense, 1972.

SANTOS, J. L. O que é cultura. São Paulo: Brasiliense, 2006.

SILVA, F. M. A idéia de sertão em José de Alencar: um estudo a partir de o Sertanejo.

Dissertação (mestrado). Universidade Federal de Mato Grosso, Instituto de Linguagens, Pósgraduação em Estudos de Linguagem, Área de Concentração: Literatura e Realidade Social, 2010.

SODRÉ, N. W. História da literatura brasileira: seus fundamentos econômicos. 4. ed. Rio de Janeiro: Civilização Brasileira, 1964. 